\title{
Quantitative Study on the Chemical Solution Deposition of Zinc Oxysulfide
}

\author{
Michael Reinisch, ${ }^{a}$ Craig L. Perkins, ${ }^{b}$ and K. Xerxes Steirer ${ }^{b, z}$ \\ ${ }^{a}$ University of Arkansas, Fayetteville, Arkansas 72701, USA \\ ${ }^{b}$ National Renewable Energy Laboratory, Golden, Colorado 80401, USA
}

\begin{abstract}
Zinc Oxysulfide (ZnOS) has demonstrated potential in the last decade to replace CdS as a buffer layer material since it is a wideband-gap semiconductor with performance advantages over CdS $\left(E_{g}=2.4 \mathrm{eV}\right)$ in the near UV-range for solar energy conversion. However, questions remain on the growth mechanisms of chemical bath deposited ZnOS. In this study, a detailed model is employed to calculate solubility diagrams that describe simple conditions for complex speciation control using only ammonium hydroxide without additional base. For these conditions, ZnOS is deposited via aqueous solution deposition on a quartz crystal microbalance in a continuous flow cell. Data is used to analyze the growth rate dependence on temperature and also to elucidate the effects of dimethylsulfoxide (DMSO) when used as a co-solvent. Activation energies $\left(\mathrm{E}_{\mathrm{A}}\right)$ of $\mathrm{ZnOS}$ are calculated for different flow rates and solution compositions. The measured $\mathrm{E}_{\mathrm{A}}$ relationships are affected by changes in the primary growth mechanism when DMSO is included.

(c) The Author(s) 2015. Published by ECS. This is an open access article distributed under the terms of the Creative Commons Attribution Non-Commercial No Derivatives 4.0 License (CC BY-NC-ND, http://creativecommons.org/licenses/by-nc-nd/4.0/), which permits non-commercial reuse, distribution, and reproduction in any medium, provided the original work is not changed in any way and is properly cited. For permission for commercial reuse, please email: oa @electrochem.org. [DOI: 10.1149/2.0201602jss] All rights reserved.
\end{abstract}

Manuscript submitted September 10, 2015; revised manuscript received November 3, 2015. Published November 21, 2015.

Solution deposition of semiconductors and in particular chemical bath deposition (CBD) has gained attention in recent years due to its inexpensive, high quality films deposited at moderate temperatures. $\mathrm{CBD}$ is well suited for producing large-area thin films for solar cell applications. ${ }^{1,2}$ It has already demonstrated the potential to produce high efficiency thin-film solar cells (TFSCs) and modules ${ }^{3}$ and is currently used to deposit buffer layers for various photovoltaic devices, including lab scale $\mathrm{CdTe}$ and commercialized copper indium gallium diselenide (CIGS) solar cells, which are technologies for clean, renewable, secure, and inexpensive energy production.

Buffer layers in TFSCs typically serve as the first n-type layer in a heterojunction with a p-type absorber layer (CIGS, CdTe, etc.). In addition to transporting photogenerated charge, the buffer layer should allow maximum light to be transmitted to the absorber layer. Currently, most high efficiency TFSCs contain CdS buffer layers that are easy to deposit due to the low solubility product constant $\left(\mathrm{K}_{\mathrm{sp}}\right)$ of $\mathrm{CdS}$ and the large difference between its $\mathrm{K}_{\mathrm{sp}}$ and competing species such as $\mathrm{Cd}(\mathrm{OH})_{2}$. However, the performance of $\mathrm{CdS}$ buffer layers is limited by its bandgap $\left(\mathrm{E}_{\mathrm{g}}=2.4 \mathrm{eV}\right)$, which absorbs blue as well as UV light. Also, the toxicity of $\mathrm{CdS}$ and its precursors poses risks and waste associated costs. ${ }^{3}$ To counter these problems, alternative buffer layer materials have been researched in the last decades. One such material is $\mathrm{ZnO}_{\mathrm{x}} \mathrm{S}_{1-\mathrm{x}}$, herein $\mathrm{ZnOS}$. ZnOS is a non-toxic semiconductor, which experimentally has demonstrated a tunable bandgap between $2.6 \mathrm{eV}$ and $3.6 \mathrm{eV} .{ }^{4}$ Although $\mathrm{ZnOS}$ has been studied extensively, there is seemingly conflicting reports on its growth mechanism in CBD. Using an open bath, quartz crystal microbalance (QCM) approach, Hubert et al. hypothesized that $\mathrm{ZnOS}$ is formed by the heterogeneous ion-by-ion process because of its similarities to the chemical reaction controlled CdS growth. ${ }^{3}$ On the other hand, kinetic studies by Gonzalez-Panzo et al. showed that $\mathrm{ZnOS}$ is deposited via the homogeneous mechanism explained by low steric hindrance between reacting species. ${ }^{5}$ Work from Shin et al. suggests further that controlling speciation may provide a route to favor either heterogeneous or homogeneous growth of $\mathrm{ZnOS} .^{6}$ While these groups advocate either the heterogeneous or homogeneous mechanism, it is probable that these mechanisms compete such that both take place. ${ }^{7}$ Furthermore, subtle factors such as additives and co-solvents in CBD can affect the film growth. For example, in Figure 1 VUV transmittance spectra collected with an integrating sphere are compared for CBD-ZnOS grown onto quartz substrates to test the effects of dimethylsulfoxide (DMSO), a co-solvent that is used to deposit superior performing $\mathrm{ZnOS}$ buffer layer films in CIGS solar cells. ${ }^{8}$ Moreover, spectroscopic characterization of $\mathrm{Cu}_{2} \mathrm{ZnSnSe}_{4} / \mathrm{ZnOS}$ heterojunctions showed that including DMSO during CBD growth of $\mathrm{ZnOS}$ affected the band energy line up but resulted in no definitive compositional changes. ${ }^{9}$ Films shown in Figure 1 were deposited with standard CBD of ZnOS on quartz substrates in an open reaction vessel that is similar for solar cell buffer layer depositions. Films grown on the quartz slides exhibit different coverage resulting in the distinctly different transmission spectra. With water as the only solvent, ZnOS films exhibit optical absorption onset near $340 \mathrm{~nm}$ and forms a closed film that covers the whole substrate. When DMSO is included in the deposition, the films appear slightly cloudy while widely spaced particles leave much of the substrate uncovered. The lowered transmission across the visible range for these adhered particles results from scattering effects. Hence, understanding the impact of DMSO and the resulting difference in nucleation and growth of $\mathrm{ZnOS}$ films is important for developing control of film growth with the use of additives and co-solvents.

In this contribution, a complete speciation model is presented in order to develop species distribution diagrams (SDD) and total solubility diagrams where the species complexation and $\mathrm{pH}$ are controlled using ammonium hydroxide without the need for added base. Reports from Gonzalez-Panzo introduced additional base into the calculations for adjusting $\mathrm{pH} .{ }^{2}$ We calculated species distribution diagrams treating the

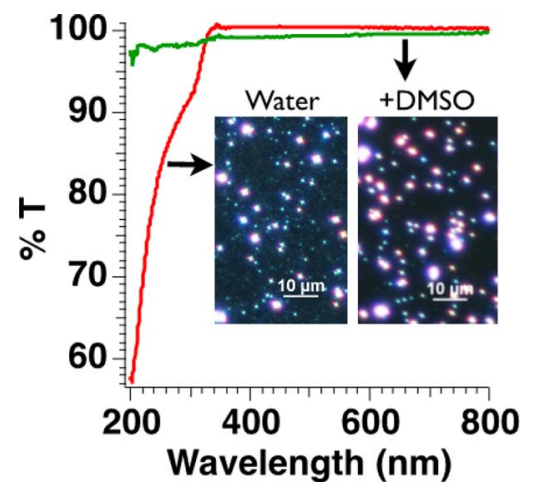

Figure 1. Transmission spectra for $\mathrm{CBD}-\mathrm{ZnOS}$ grown on quartz with (green) and without (red) DMSO. Inset: darkfield optical microscope images of samples indicated. 


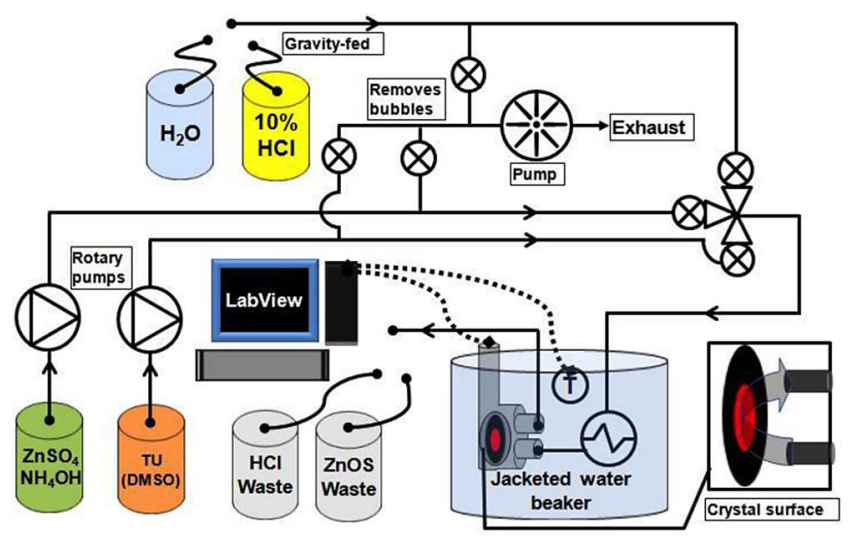

Figure 2. Flow schematic for the QCM integrated continuous solution deposition system first reported in Ref. 20.

previously published low ammonia concentrations with the present, higher ammonia concentrations. In previous reports, the species distribution diagrams that consider ammonia were calculated at $298 \mathrm{~K}$ and $333 \mathrm{~K}$ while our bath chemistry is at $353 \mathrm{~K} .{ }^{10}$ An important result is that the SDDs look different. Resulting SDDs provide insight on a simple approach to control zinc speciation. This approach is used to help understand experimentally determined activation energies and gain a better understanding of the growth mechanism for $\mathrm{ZnOS}$. $\mathrm{ZnOS}$ thin films are deposited on a QCM in a continuous liquid flow-cell system to achieve highly reproducible and controlled growth. The temperature and flow rate of the bath are varied to determine their effects on $\mathrm{ZnOS}$ growth while comparing the effects for DMSO on the dominant growth mechanism.

\section{Materials and Methods}

Materials. - Zinc sulfate heptahydrate $\left(\mathrm{ZnSO}_{4} \bullet 7 \mathrm{H}_{2} \mathrm{O}, 99.999 \%\right.$ pure) served as a source of zinc ions, and recrystallized thiourea $\left(\mathrm{SC}\left(\mathrm{NH}_{2}\right)_{2}\right)$ as a source of sulfide ions. Ammonium hydroxide $\left(\mathrm{NH}_{4} \mathrm{OH}, 28-30 \%, \sim 15.54 \mathrm{M}\right)$ was used to vary the ligand concentration and increase $\mathrm{pH}$ simultaneously. DI water was degassed to minimize dissolved oxygen. Reagent grade dimethylsulfoxide $\left(\left(\mathrm{CH}_{3}\right)_{2} \mathrm{OS}\right.$, DMSO) was used as received.

ZnOS deposition.- Depositions for growth studies were carried out on an AT-cut Quartz Crystal Microbalance (QCM, $5 \mathrm{MHz}$ ) in a nitrogen purged glove box. The $\mathrm{Ti} / \mathrm{Au} / \mathrm{Ti} / \mathrm{SiO}_{2}$ (Maxtek) crystal surface has a total exposed area of $137 \mathrm{~mm}^{2}$ and an active oscillation area of $34.17 \mathrm{~mm}^{2}$. Figure 2 is a flow schematic of the system. The Maxtek FC-550 QCM flow cell (volume $=0.1 \mathrm{ml}$ ) was immersed in a jacketed water beaker while connected to an inlet/outlet that isolated the chemical solution from the heated water bath. The jacketed water beaker was covered with a Teflon cap that prevents water evaporation and heat losses. Solutions were connected to separate rotary pumps that control the flow rates. The separate flow streams combine and mix in a computer controlled mixing valve that also served to start and stop flow of reagents. A vacuum pump connected to contact degassers was used to remove bubbles from each reactant stream before the streams combined in the mixing valve. After mixing, the reactant stream was brought to the same temperature as the QCM assembly by a stainless steel heat exchanger coil that connects to the flow cell inlet tube. A thermocouple probe monitored the temperature in the reservoir. From the crystal surface, the reactants move to the outlet that leads to the waste container.

A deposition is illustrated in Figure 3 with a measured data set. Solution flows are initiated after the QCM has equilibrated with the temperature of the reservoir. At a total flow rate of $40 \mu \mathrm{L} / \mathrm{s}$ it takes one minute for the reactants to travel from the mixing valve to the crystal surface where they deposit. The system is in dynamic equilibrium

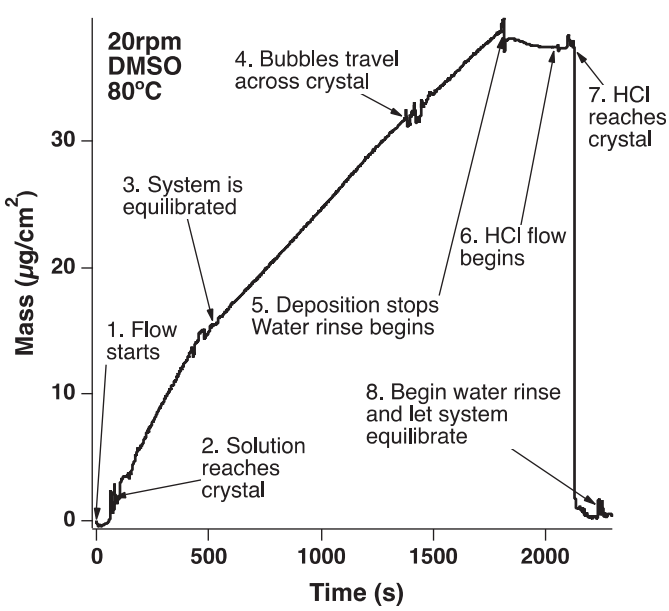

Figure 3. Graph of $\mathrm{ZnOS}$ mass deposited versus time in QCM flow cell. Theoretical basis for analysis of the QCM frequency response follows $\mathrm{Lu}$ and Lewis ${ }^{21}$ with the ratio of acoustic impedance for $\mathrm{ZnOS}$ and quartz $\left(\mathrm{R}_{\mathrm{z}}\right)$ equal to unity. 22

once the observed growth rate onto the crystal is linear. We observe that it takes at most 15 minutes to achieve quasi steady-state conditions. In practice, the system may not reach chemical equilibrium in the flow cell because the reactants only mix for one to two minutes before reaching the crystal. In that regard, the theoretical model is not an exact description of the bath chemistry tested. However, since the zinc-ammonia solution is initially equilibrated in the same container and flow line, calculated species distribution diagrams maintain the dominant complexation occurring with 1 to 2 minute residence times. Therefore, the reported growth rates are calculated from fits to the QCM data between the 15 and 30 minute marks. Depositions are carried out for 30 minutes, after which the reactant streams are halted and the water stream is turned on to purge the system. After approximately 30 seconds, the water stream is stopped, and the $\mathrm{HCl}$ stream is turned on to remove the deposited $\mathrm{ZnOS}$ layer. Once the QCM registers the film removal, the $\mathrm{HCl}$ stream is stopped, and the water stream is turned on for several minutes to ensure that no $\mathrm{HCl}$ remains.

Experiment.- Two sets of bath compositions were tested in this study. $\mathrm{NH}_{4} \mathrm{OH}$ was used to simultaneously control speciation and $\mathrm{pH}$ as described in the Speciation model section. The first set contains solutions that combine and mix as described above without DMSO. The second set includes DMSO, which replaces the same volume of water in order to keep all the other concentrations the same. Stream A supplies the zinc cations and consists of $\mathrm{ZnSO}_{4}(0.0218 \mathrm{M})$ and $\mathrm{NH}_{4} \mathrm{OH}(6.68 \mathrm{M})$ in DI water. Stream B supplies the sulfur from $\mathrm{SC}\left(\mathrm{NH}_{2}\right)_{2}(1.13 \mathrm{M})$ in DI water. The second set utilized identical concentrations with Stream A having replaced DI to obtain $12 \mathrm{v} / \mathrm{v} \%$ DMSO $(4.82 \mathrm{M})$. Solutions were prepared fresh prior to each set of experiments. During depositions, the flow rates of the two streams were equal. Hence, combining streams A and B halved all the original concentrations. This resulted in deposition solutions with concentrations of $\mathrm{ZnSO}_{4}(0.0109 \mathrm{M}), \mathrm{NH}_{4} \mathrm{OH}(3.34 \mathrm{M}), \mathrm{SC}\left(\mathrm{NH}_{2}\right)_{2}(0.565 \mathrm{M})$ and for the second set, $6 \mathrm{v} / \mathrm{v} \%$ DMSO $(2.82 \mathrm{M})$. Depositions used total flow rates of $20 \mu \mathrm{L} / \mathrm{s}, 30 \mu \mathrm{L} / \mathrm{s}$, and $40 \mu \mathrm{L} / \mathrm{s}$.

\section{Results and Discussion}

Speciation model. - To develop a model of the bath chemistry, one must first calculate the concentrations of each species in the solution. These include the zinc complexes, thiourea derivatives, and free species such as ammonia, the zinc ion, the hydroxide ion, and the hydrogen ion. Although the Zn-DMSO-water system was treated by Gaizer and Silber, the stability constants for the Zn-DMSO-waterammonia system are currently unavailable. ${ }^{23}$ Equilibrium constants 
for the dissociation of thiourea, ammonia, and water, as well as the stability constants for zinc complexes, are derived from the curvefitting parameters reported by Gonzalez-Panzo et al. ${ }^{2}$

Calculation of sulfur ion concentration.-The sulfur ion concentration is determined by the decomposition of thiourea, which decomposes into hydrogen sulfide $\left(\mathrm{H}_{2} \mathrm{~S}\right)$ and cyanamide $\left(\mathrm{H}_{2} \mathrm{NCN}\right)$. Both of these products dissociate further by each losing two protons. Following González-Panzo et al., ${ }^{2}$ the complete dissociation mechanism of thiourea is given in Equations 1-5. The left column comprises the chemical reactions while the right column displays the respective equilibrium reactions.

$$
\begin{array}{lr}
S C\left(\mathrm{NH}_{2}\right)_{2} \leftrightarrow \mathrm{H}_{2} \mathrm{~S}+\mathrm{H}_{2} \mathrm{NCN} & K_{1}=\frac{\left[\mathrm{H}_{2} \mathrm{~S}\right]\left[\mathrm{H}_{2} \mathrm{NCN}\right]}{\left[S C\left(\mathrm{NH}_{2}\right)_{2}\right]} \\
\mathrm{H}_{2} \mathrm{NCN} \leftrightarrow H N C N^{-}+H^{+} & K_{2}=\frac{\left[H N C N^{-}\right]\left[\mathrm{H}^{+}\right]}{\left[\mathrm{H}_{2} \mathrm{NCN}\right]} \\
H N C N^{-} \leftrightarrow N C N^{2-}+H^{+} & K_{3}=\frac{\left[N C N^{2-}\right]\left[H^{+}\right]}{\left[H N C N^{-}\right]} \\
H_{2} S \leftrightarrow H S^{-}+H^{+} & K_{4}=\frac{\left[H S^{-}\right]\left[H^{+}\right]}{\left[H_{2} S\right]} \\
H S^{-} \leftrightarrow S^{2-}+H^{+} & K_{5}=\frac{\left[S^{2-}\right]\left[H^{+}\right]}{\left[H S^{-}\right]}
\end{array}
$$

The overall balance for Equations $1-5$ is given in Equation 6. The input value in the calculation, $\left[\mathrm{SC}\left(\mathrm{NH}_{2}\right)_{2}\right]_{\text {total }}$ represents the total amount of thiourea added to the system.

$$
\begin{aligned}
2[S C & \left.\left(\mathrm{NH}_{2}\right)_{2}\right]_{\text {total }} \\
= & 2\left[\mathrm{SC}\left(\mathrm{NH}_{2}\right)_{2}\right](a q)+\left[\mathrm{H}_{2} \mathrm{NCN}\right](a q) \\
& +\left[\mathrm{HNCN}^{-}\right](a q)+\left[\mathrm{NCN}^{2-}\right](a q) \\
& +\left[\mathrm{H}_{2} \mathrm{~S}\right](a q)+\left[\mathrm{HS}^{-}\right](a q)+\left[\mathrm{S}^{2-}\right](a q)
\end{aligned}
$$

The equilibrium constants for the decomposition of thiourea at various temperatures is provided in Table I. The decrease in $\mathrm{pK}$ demonstrates that more dissociation takes place at higher temperatures, resulting in the increase of the sulfide ion concentration.

Calculation of ammonia concentration.-The ammonia concentration is calculated from the hydrogen ion concentration and the formation constants of zinc ammonia complexes. The balance for ammonia is given below in Equation 7.

$$
\begin{aligned}
{\left[\mathrm{NH}_{3}\right]_{\text {total }}=} & {\left[\mathrm{NH}_{3}\right](\mathrm{aq})+\left[\mathrm{NH}_{4}^{+}\right](\mathrm{aq})+\left[\mathrm{Zn}\left(\mathrm{NH}_{3}\right)^{2+}\right](\mathrm{aq}) } \\
& +2\left[\mathrm{Zn}\left(\mathrm{NH}_{3}\right)_{2}^{2+}\right](\mathrm{aq})+3\left[\mathrm{Zn}\left(\mathrm{NH}_{3}\right)_{3}^{2+}\right](a q) \\
& +4\left[\mathrm{Zn}\left(\mathrm{NH}_{3}\right)_{4}^{2+}\right](a q)
\end{aligned}
$$

The total ammonia concentration $\left(\left[\mathrm{NH}_{3}\right]_{\text {total }}\right)$ is the input variable while the free ammonia concentration $\left(\left[\mathrm{NH}_{3}\right]\right)$ is the output variable. All the other variables in Equation 7 are written as a function of the zinc ion concentration, the ammonia concentration, and the hydrogen ion concentration as given below in Equations 8-12.

Table I. A summary of the equilibrium constants at various temperatures for the decomposition of thiourea. The constants are given in the form of the negative logarithm (pK).

\section{$25^{\circ} \mathrm{C}$}

pK1 22.35

pk2 10.36

pK3 11.23

pK4 6.99

pK5

17.24 $30^{\circ} \mathrm{C} \quad 40^{\circ} \mathrm{C}$

$22.07 \quad 21.52$

$10.28 \quad 10.14$

$11.04 \quad 10.70$

$6.92 \quad 6.80$

17.13

$\begin{array}{ll}6.80 & 6.70\end{array}$

$16.92 \quad 16.73$

$60^{\circ} \mathrm{C}$

20.38

9.88

9.88
10.13

6.62

16.55 $70^{\circ} \mathrm{C} \quad 80^{\circ} \mathrm{C} \quad 90^{\circ} \mathrm{C}$

$\begin{array}{lll}19.82 & 19.24 & 18.67\end{array}$

$\begin{array}{lll}9.75 & 9.63 & 9.52\end{array}$

$\begin{array}{lll}9.90 & 9.69 & 9.52\end{array}$

$\begin{array}{lll}6.56 & 6.52 & 6.49\end{array}$

$\begin{array}{lll}16.39 & 16.23 & 16.09\end{array}$
Table II. A summary of the pK values of ammonia and the four zinc complexes formed at various temperatures.

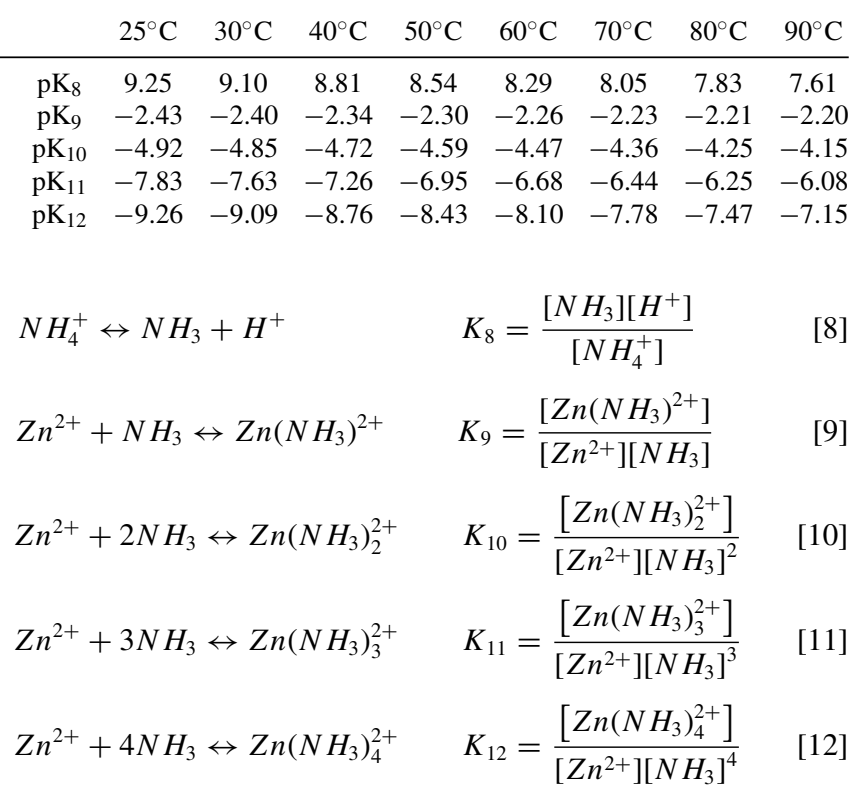

$\begin{array}{lllllllll}\mathrm{pK}_{8} & 9.25 & 9.10 & 8.81 & 8.54 & 8.29 & 8.05 & 7.83 & 7.61\end{array}$

The $\mathrm{pK}$ values for Equations 8-12 at various temperatures are reported in Table II. More negative $\mathrm{pK}$ values mean that the product is favored, and more positive $\mathrm{pK}$ values mean that the reactants are favored. This indicates that as the temperature is raised, the concentrations of zinc amino complexes are increased.

Calculation of zinc ion concentration.-The zinc ion concentration is calculated from a number of competing zinc species: the precipitation of $\mathrm{ZnS}$ and $\mathrm{Zn}(\mathrm{OH})_{2}$, and the formation of zinc complexes, $\mathrm{Zn}(\mathrm{OH})^{+}, \mathrm{Zn}(\mathrm{OH})_{2}, \mathrm{Zn}(\mathrm{OH})_{3}{ }^{-}, \mathrm{Zn}(\mathrm{OH})_{4}{ }^{2-}, \mathrm{Zn}\left(\mathrm{NH}_{3}\right)^{2+}$, $\mathrm{Zn}\left(\mathrm{NH}_{3}\right)_{2}{ }^{2+}, \mathrm{Zn}\left(\mathrm{NH}_{3}\right)_{3}{ }^{2+}$, and $\mathrm{Zn}\left(\mathrm{NH}_{3}\right)_{4}{ }^{2+}$. The zinc mass balance is given below in Equation 13. [Zn $]_{\text {total }}$ is the concentration of all zinc species in the bath and serves as an input variable to the model.

$$
\begin{aligned}
{[\mathrm{Zn}]_{\text {total }}=} & {[\mathrm{ZnS}](s)+\left[\mathrm{Zn}(\mathrm{OH})_{2}\right](s)+\left[\mathrm{Zn}^{2+}\right](a q) } \\
& +\left[\mathrm{Zn}\left(\mathrm{NH}_{3}\right)^{2+}\right](a q)+\left[\mathrm{Zn}\left(\mathrm{NH}_{3}\right)_{2}^{2+}\right](a q) \\
& +\left[\mathrm{Zn}\left(\mathrm{NH}_{3}\right)_{3}^{2+}\right](a q)+\left[\mathrm{Zn}\left(\mathrm{NH}_{3}\right)_{4}^{2+}\right](a q) \\
& +\left[\mathrm{Zn}(\mathrm{OH})^{-}\right](a q)+\left[\mathrm{Zn}(\mathrm{OH})_{2}\right](a q) \\
& +\left[\mathrm{Zn}(\mathrm{OH})_{3}^{-}\right](a q)+\left[\mathrm{Zn}(\mathrm{OH})_{4}^{2-}\right](a q)
\end{aligned}
$$

The precipitation of $\mathrm{ZnS}$ and $\mathrm{Zn}(\mathrm{OH})_{2}$ are calculated using their respective solubility product constants and anion concentrations as given below in Equations 14 and 15.

$$
\begin{gathered}
{\left[\mathrm{Zn}^{2+}\right]=\frac{K s p_{\mathrm{ZnS}}}{\left[\mathrm{S}^{2-}\right]}} \\
{\left[\mathrm{Zn}^{2+}\right]=\frac{K s p_{\mathrm{Zn}\left(\mathrm{OH}_{2}\right)}}{\left[\mathrm{OH} \mathrm{H}^{-}\right.}}
\end{gathered}
$$

where $\left[\mathrm{S}^{2-}\right]$ is calculated in the previous section, and $\left[\mathrm{OH}^{-}\right]$is calculated from $\mathrm{pH}$, which is either an input variable, or it is calculated from the ammonium hydroxide concentration. Unlike the other equilibrium constants, the solubility products of $\mathrm{ZnS}$ and $\mathrm{ZnOH}_{2}$ were taken from Goux et al. (2004), Hubert et al. (2006), and Hubert et al. (2007) $)^{10-12}$ who use the same set of values. These values are only available at discrete temperature values and do not have curve-fitting parameters associated with them. Table III contains the $\mathrm{pK}_{\mathrm{sp}}$ values for $\mathrm{ZnOH}_{2}$ and $\mathrm{ZnS}$ at $25^{\circ} \mathrm{C}, 50^{\circ} \mathrm{C}, 60^{\circ} \mathrm{C}, 70^{\circ} \mathrm{C}, 80^{\circ} \mathrm{C}$, and $90^{\circ} \mathrm{C}$.

The concentrations of the four zinc hydroxide complexes are calculated from the zinc ion and the hydroxide concentrations. This calculation is iterative, which is why the free zinc ion concentration 
Table III. A summary of the $\mathrm{pK}_{\mathrm{sp}}$ values of zinc hydroxide and zinc sulfide at various temperatures.

\begin{tabular}{lllllll} 
& $25^{\circ} \mathrm{C}$ & $50^{\circ} \mathrm{C}$ & $60^{\circ} \mathrm{C}$ & $70^{\circ} \mathrm{C}$ & $80^{\circ} \mathrm{C}$ & $90^{\circ} \mathrm{C}$ \\
\hline $\mathrm{pK}_{14}$ & 22.58 & 21.65 & 21.33 & 21.05 & 20.80 & 20.57 \\
$\mathrm{pK}_{15}$ & 16.49 & 16.11 & 16.00 & 15.92 & 15.85 & 15.79
\end{tabular}

depends on the concentration of the complexes and vice versa. The chemical reactions and equilibrium expressions are given below in Equations 16 to 19 .

$$
\begin{array}{ll}
\mathrm{Zn}^{2+}+\mathrm{OH}^{-} \leftrightarrow \mathrm{Zn}(\mathrm{OH})^{+} & K_{16}=\frac{\left[\mathrm{Zn}(\mathrm{OH})^{+}\right]}{\left[\mathrm{Zn} n^{2+}\right]\left[\mathrm{OH}^{-}\right]} \\
\mathrm{Zn}^{2+}+2 \mathrm{OH}^{-} \leftrightarrow \mathrm{Zn}(\mathrm{OH})_{2} & K_{17}=\frac{\left[\mathrm{Zn}(\mathrm{OH})_{2}\right]}{\left[\mathrm{Zn}^{2+}\right]\left[\mathrm{OH}^{-}\right]^{2}} \\
\mathrm{Zn}^{2+}+3 \mathrm{OH}^{-} \leftrightarrow \mathrm{Zn}(\mathrm{OH})_{3}^{-} & K_{18}=\frac{\left[\mathrm{Zn}(\mathrm{OH})_{3}^{-}\right]}{\left[\mathrm{Zn} n^{2+}\right]\left[\mathrm{OH}^{-}\right]^{3}} \\
\mathrm{Zn}^{2+}+4 O \mathrm{OH}^{-} \leftrightarrow \mathrm{Zn}(\mathrm{OH})_{4}^{2-} & K_{19}=\frac{\left[\mathrm{Zn}(\mathrm{OH})_{4}^{2-}\right]}{\left[\mathrm{Zn}^{2+}\right]\left[\mathrm{OH}^{-}\right]^{4}}
\end{array}
$$

The $\mathrm{pK}$ values for Equations 16-19 at various temperatures are given in Table IV. These constants are much lower than the zinc ammonia constants. Hence, the hydroxide concentration is lower than the ammonia concentration and the zinc amino complexes make up a larger fraction of the species in the bath.

There are three ways in which the bath consumes zinc ions: the precipitation of $\mathrm{Zn}(\mathrm{OH})_{2}$, the precipitation of $\mathrm{ZnS}$, and the formation of the various zinc complexes. The zinc ion concentration in the bath is determined by the lowest value among these three factors using Equation 20 below. competing mechanisms have to be considered. Another homogeneous mechanism is one where zinc is first complexed by ammonia. The resulting zinc tetraamino (II) complex is more stable and more abundant in the bath than free zinc ions. Hence, a precipitation reaction with a complex is more likely than one with the free zinc ions in the present case. These two reactions are shown below in Equations 23 and 24.

$$
\begin{aligned}
& \mathrm{Zn}\left(\mathrm{NH}_{3}\right)_{4}^{2+}(a q)+\mathrm{S}^{2-}(a q) \rightarrow \mathrm{ZnS}(s)+4 \mathrm{NH}_{3}(a q) \\
& \mathrm{Zn}\left(\mathrm{NH}_{3}\right)_{4}^{2+}(a q)+2 \mathrm{OH}^{-}(a q) \rightarrow \mathrm{Zn}(\mathrm{OH})_{2}(s)+4 \mathrm{NH}_{3}(a q)
\end{aligned}
$$

According to the heterogeneous mechanism, or "ion-by-ion" mechanism, individual ions first adsorb onto the surface and then react with their respective counterparts. This mechanism is described in Equations 25 and 26. Note that it is less likely for this ion-by-ion mechanism to proceed by adsorbing the tetraamino complex, because it is sterically hindered. ${ }^{13}$

$$
Z n(O, O H, S)-Z n^{2+}(a q)+S^{2-}(a q) \rightarrow Z n(O, O H, S)-Z n S(s)
$$

$$
\begin{gathered}
\mathrm{Zn}(\mathrm{O}, \mathrm{OH}, \mathrm{S})-\mathrm{Zn}^{2+}(a q)+2 \mathrm{OH}^{-}(a q) \\
\rightarrow \mathrm{Zn}(\mathrm{O}, \mathrm{OH}, \mathrm{S})-\mathrm{Zn}(\mathrm{OH})_{2}(s)
\end{gathered}
$$

A third mechanism, called the "cluster-by-cluster" mechanism, is both a homogeneous and heterogeneous mechanism, because the cluster first forms according to the homogeneous mechanism described in Equations 21-24, and the clusters grow according to the heterogeneous mechanism described in Equations 25 and 26. ${ }^{14}$

Model calculations. - SDDs are used to analyze which ions comprise a majority of the active chemical species in a solution. SDDs are generated using the concentration of each reagent and the stability constants of all considered complexes at the desired tempera-

$$
\begin{aligned}
{\left[\mathrm{Zn}^{2+}\right]=} & \min \left(\frac{K s p_{Z n\left(O H_{2}\right)}}{\left[\mathrm{OH}^{-}\right]^{2}}, \frac{K s p_{Z n S}}{\left[S^{2-}\right]},\right. \\
& \left.\frac{[\mathrm{Zn}]_{\text {total }}}{\left(1+K_{9}\left[\mathrm{NH}_{3}\right]+K_{10}\left[\mathrm{NH}_{3}\right]^{2}+K_{11}\left[\mathrm{NH}_{3}\right]^{3}+K_{12}\left[\mathrm{NH}_{3}\right]^{4}+K_{16}\left[\mathrm{OH}^{-}\right]+K_{17}\left[\mathrm{OH}^{-}\right]^{2}+K_{18}\left[\mathrm{OH}^{-}\right]^{3}+K_{19}\left[\mathrm{OH}^{-}\right]^{4}\right)}\right)
\end{aligned}
$$

Formation of zinc species.-The major mechanisms explaining the precipitation of $\mathrm{Zn}(\mathrm{OH})_{2}$ and $\mathrm{ZnS}$ are the homogeneous mechanism and the heterogeneous mechanism. According to the homogeneous mechanism, a free zinc ion reacts with either a sulfur anion or two hydroxide anions as shown in Equations 21 and 22. The precipitated compound then adheres to the surface.

$$
\begin{array}{r}
\mathrm{Zn}^{2+}(a q)+\mathrm{S}^{2-}(a q) \rightarrow \mathrm{ZnS}(s) \\
\mathrm{Zn}^{2+}(a q)+2 \mathrm{OH}^{-}(a q) \rightarrow \mathrm{Zn}(\mathrm{OH})_{2}(s)
\end{array}
$$

Although this homogeneous mechanism seems likely due to the low solubility product constants and minimal steric hindrance, the concentrations of free sulfur anions and zinc ions are very low and

Table IV. A summary of the equilibrium constants of zinc hydroxide complexes between $25^{\circ} \mathrm{C}$ and $90^{\circ} \mathrm{C}$.

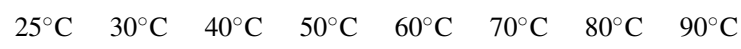

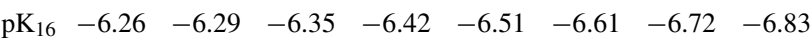

$\mathrm{pK}_{17}-10.22-10.17-10.09-10.04-10.03-10.04-10.08-10.14$

$\mathrm{pK}_{18}-14.39-14.23-13.96-13.74-13.58-13.45-13.37-13.32$

$\mathrm{pK}_{19}-15.61-15.42-15.07-14.79-14.57-14.40-14.27-14.18$ ture. In this study, SDDs were generated for the system $\mathrm{Zn}-\mathrm{H}_{2} \mathrm{O}-\mathrm{NH}_{3}$ for four temperatures $\left(\mathrm{T}=25^{\circ} \mathrm{C}, 40^{\circ} \mathrm{C}, 60^{\circ}\right.$, and $\left.80^{\circ} \mathrm{C}\right)$ and two concentrations of ammonia. The ammonia concentration reported by Gonzales-Panzo et al. ${ }^{2,15}\left(\left[\mathrm{NH}_{3}\right]=0.273 \mathrm{M}\right)$ was compared to one that is much higher, demonstrated in high performance buffer layers in solar cells and used throughout the experiments performed in this study $\left(\left[\mathrm{NH}_{3}\right]=3.34 \mathrm{M}\right)$.

SDDs in Figure 4 were generated using solubility product constants, stability constants, and other equilibrium constants that explain the precipitation of zinc compounds, the formation of zinc complexes, and the decomposition of thiourea as described above. The calculations behind the theoretical model were applied to successfully recreate the solubility and species distribution diagrams of four journal papers..$^{2,10-12}$ Solubility curves and SDDs are graphed as a function of $\mathrm{pH}$ by considering the equilibrium expressions of each species in solution. These equilibrium expressions include ammonia to the ammonium ion, the zinc ion to its four hydroxide complexes, $\mathrm{Zn}(\mathrm{OH})^{+}$, $\mathrm{Zn}(\mathrm{OH})_{2}, \mathrm{Zn}(\mathrm{OH})_{3}{ }^{-}$, and $\mathrm{Zn}(\mathrm{OH})_{4}{ }^{2-}$, as well as its four ammonium complexes, $\mathrm{Zn}\left(\mathrm{NH}_{3}\right)^{2+}, \mathrm{Zn}\left(\mathrm{NH}_{3}\right)_{2}{ }^{2+}, \mathrm{Zn}\left(\mathrm{NH}_{3}\right)_{3}{ }^{2+}, \mathrm{Zn}\left(\mathrm{NH}_{3}\right)_{4}{ }^{2+}$. The left panel in Figure 4 shows SDDs for the $0.273 \mathrm{M}$ ammonia concentration. For this series, the $\mathrm{pH}$ increases from left to right of each SDD. The conditions favoring the higher complex concentrations remove the free zinc ions from solution thereby slowing their precipitation during CBD. As temperature increases, the equilibrium constants for zinc 

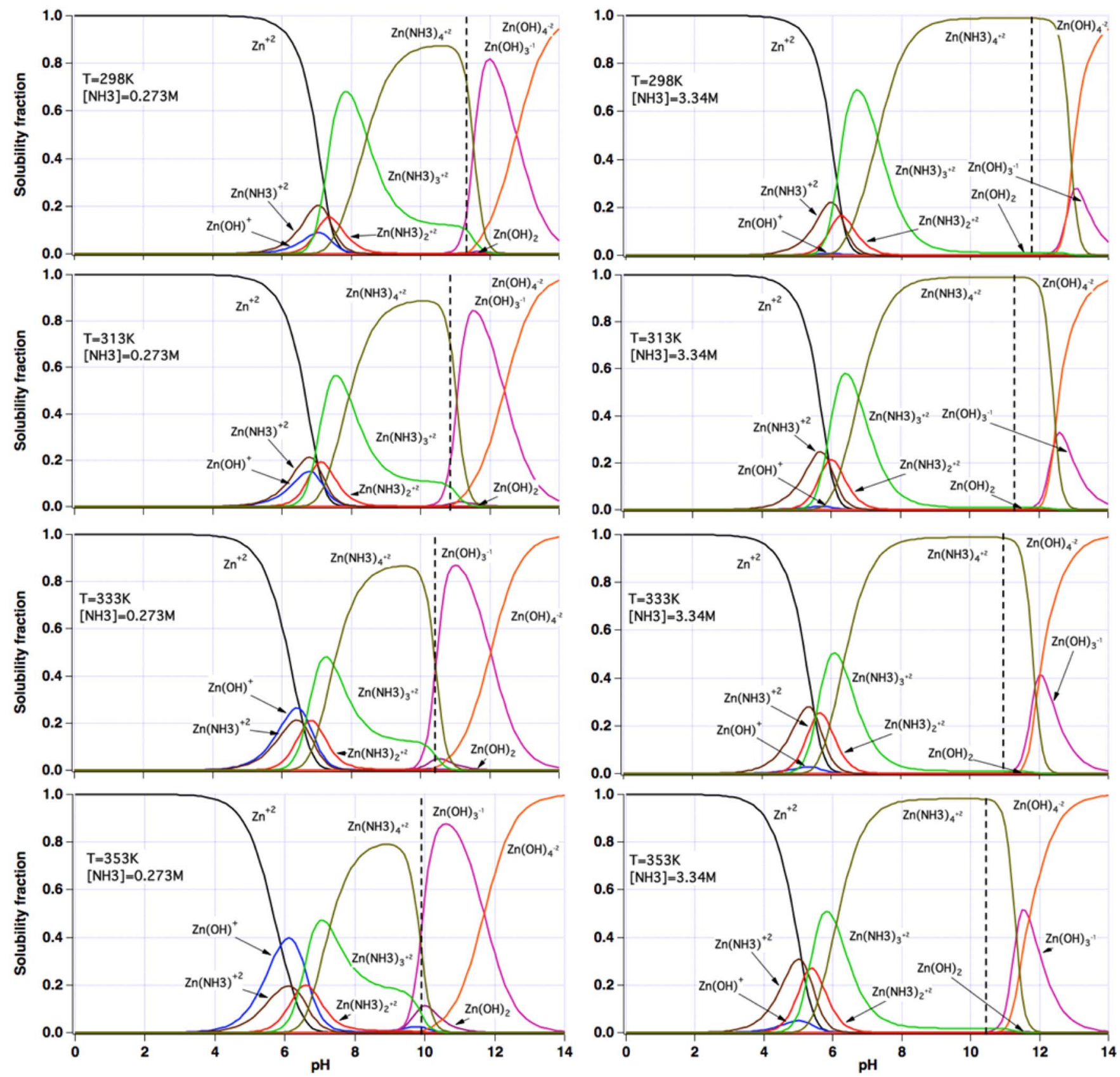

Figure 4. SDDs for the system $\mathrm{Zn}-\mathrm{H}_{2} \mathrm{O}-\mathrm{NH}_{3}$. The vertical dashed line in each diagram represents the $\mathrm{pH}$ at which the deposition would take place if the respective ammonia concentrations were achieved by the addition of ammonium hydroxide $\left(\mathrm{NH}_{4} \mathrm{OH}\right)$.

amino complexes decrease while those for the zinc hydroxide complexes increase. This change causes the relative solubility fraction of zinc hydroxide complexes to increase at any $\mathrm{pH}$ value. The vertical dotted lines mark the $\mathrm{pH}$ values if only ammonium hydroxide was used to achieve the respective ammonia concentration. As the temperature increases, the $\mathrm{pH}$ also naturally shifts from water dissociation, which lowers $\mathrm{pK}_{\mathrm{w}}$. Hence, the optimal $\mathrm{pH}$ for film growth shifts lower with increasing temperature and the changing solubility curves. The right panel of Figure 4 shows SDDs for the $3.34 \mathrm{M}$ ammonia concentration. Compared to the $0.273 \mathrm{M}$ ammonia concentration, conditions are such that the $\mathrm{Zn}\left(\mathrm{NH}_{3}\right)_{4}{ }^{2+}$ formation is strongly favored among a wide range of $\mathrm{pH}$ values. Increasing temperature also increases $\mathrm{Zn}$ hydroxide complex formation but to a much lesser degree. In this series of SDDs, the vertical dashed lines again indicate the $\mathrm{pH}$ obtained using only ammonium hydroxide and show a bath composition with almost entirely the $\mathrm{Zn}\left(\mathrm{NH}_{3}\right)_{4}{ }^{2+}$ complex, the desirable species for
CBD ZnS. Again as the temperature is increased, lower $\mathrm{pK}_{\mathrm{w}}$ shifts the solubility curves and the optimal growth conditions to lower $\mathrm{pH}$ values.

Although these SDDs display which species are dominant in a solution, they do not provide an insight into the total solubility of zinc species. Due to their low solubility products, $\mathrm{ZnS}\left(\mathrm{pK}_{\mathrm{sp}}=22.58\right)$ and $\mathrm{Zn}(\mathrm{OH})_{2}\left(\mathrm{pK}_{\mathrm{sp}}=16.49\right)^{10}$ will precipitate rapidly if the release of free zinc ions is not slowed down considerably. ${ }^{7}$ Ammonia achieves this by removing free zinc ions from solution and forming zinc amino complexes at higher $\mathrm{pH}$ values as shown in Figure 4. Figure 5 shows the total solubility modeled for zinc species as a function of the ammonium hydroxide $\left(\mathrm{NH}_{4} \mathrm{OH}\right)$ concentration at $298 \mathrm{~K}$ and $353 \mathrm{~K}$. Because ammonia complexes with zinc, the total solubility of zinc species increases significantly as the ammonia concentration increases. The graphs also show that the solubility of zinc species decreases with increasing temperature. This can be explained by the decrease in the 


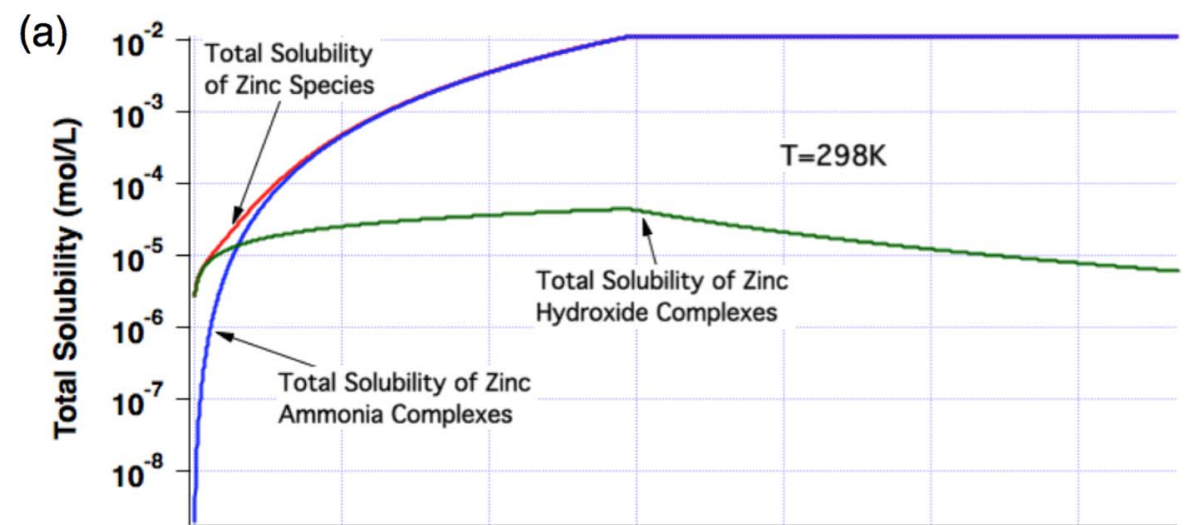

(b)

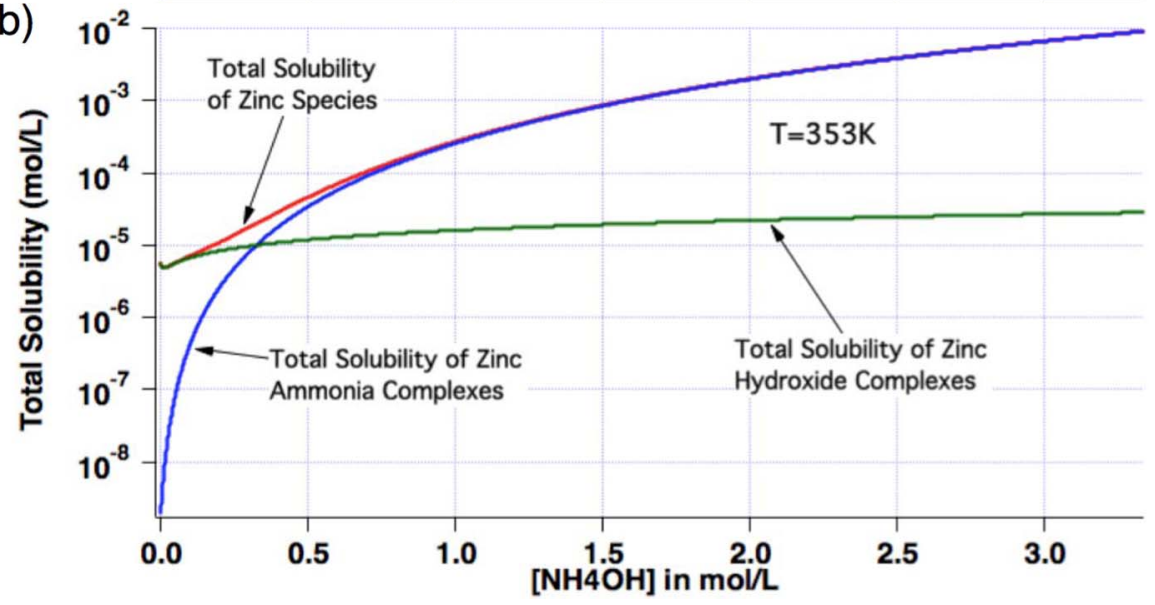

Figure 5. Total solubility diagrams for the system $\mathrm{Zn}-\mathrm{TU}-\mathrm{H}_{2} \mathrm{O}-\mathrm{NH}_{3}$ at (a) $298 \mathrm{~K}$ and (b) $353 \mathrm{~K}$. stability constants of ammonia as temperature increases, causing less complexation to occur for any given concentration of ammonia. In Figure $5 \mathrm{a}$, the total solubility of zinc hydroxide complexes decreases after an ammonia concentration of $\left[\mathrm{NH}_{3}\right]=1.5 \mathrm{M}$. This decrease occurs because once the zinc species reach their maximum solubility, the zinc complexes selectively with ammonia as the ammonia concentration is increased further.

Ammonia is not only used as a complexing agent. Ammonia is also a weak base that will convert to its conjugate acid, the ammonium ion $\left(\mathrm{NH}_{4}{ }^{+}\right)$, and simultaneously increase the $\mathrm{pH}$ of the solution. In fact, $\mathrm{NH}_{4} \mathrm{OH}$ can provide complexing and high $\mathrm{pH}$ in the solution without the need of additional base such as $\mathrm{KOH}$ as already shown in Figure 4. The effect of $\mathrm{NH}_{4} \mathrm{OH}$ on the relative speciation and the $\mathrm{pH}$ without added base is shown in Figure 6. Figures $6 \mathrm{a}$ and $6 \mathrm{~b}$ show $\mathrm{SDDs}$ for $\mathrm{NH}_{4} \mathrm{OH}$ solution concentrations between $0.003 \mathrm{M}$ to $3.34 \mathrm{M}$ at $298 \mathrm{~K}$ and $353 \mathrm{~K}$ respectively. Note that the ammonia concentration has a significant impact on the relative speciation and the total solubility of zinc in the solution. Low $\mathrm{NH}_{4} \mathrm{OH}$ concentrations result in significant hydroxide speciation. High $\mathrm{NH}_{4} \mathrm{OH}$ concentrations above $1 \mathrm{M}$ result in solution conditions with the preferred $\mathrm{Zn}\left(\mathrm{NH}_{3}\right)_{4}{ }^{2+}$ complex favoring $\mathrm{ZnS}$ film growth. When the temperature is increased from $298 \mathrm{~K}$ to $353 \mathrm{~K}$, the $\mathrm{pH}$ range lowers significantly due to the decrease in the ionic product of water, $\mathrm{pK}_{\mathrm{w}}$ as discussed above.

When an ammonia molecule is protonated to an ammonium ion, a hydroxide molecule is generated at the same time. Therefore, the ammonium ion concentration is equal to the hydroxide concentration (for $\left[\mathrm{NH}_{4} \mathrm{OH}\right] \gg 10^{-7}$ ). The concentrations of ammonium and hydroxide, as well as the resulting $\mathrm{pH}$, can be calculated using the acid dissociation constant of the ammonium ion. This results in Figure 7, which is a contour plot of total solubility versus $\mathrm{pH}$ where the $\mathrm{NH}_{4} \mathrm{OH}$ concentration is varied. As the $\mathrm{NH}_{4} \mathrm{OH}$ concentration is increased from $0.003 \mathrm{M}$ to $3.34 \mathrm{M}$, the zinc solubility increases more than three orders of magnitude. The reason for this is that high $\mathrm{NH}_{4} \mathrm{OH}$ concentrations favor higher ammonia complexes as shown in Figure 6 . The blue line in Figure 7 represents the achieved total solubility and $\mathrm{pH}$ if ammonium hydroxide $\left(\mathrm{NH}_{4} \mathrm{OH}\right)$ was used to vary the $\mathrm{pH}$ and the ammonia concentration, which is the case shown in Figure $6 \mathrm{~b}$. The blue line in Figure 7 crosses the contour lines steeply from near the lowest solubility point to near the solubility limit of
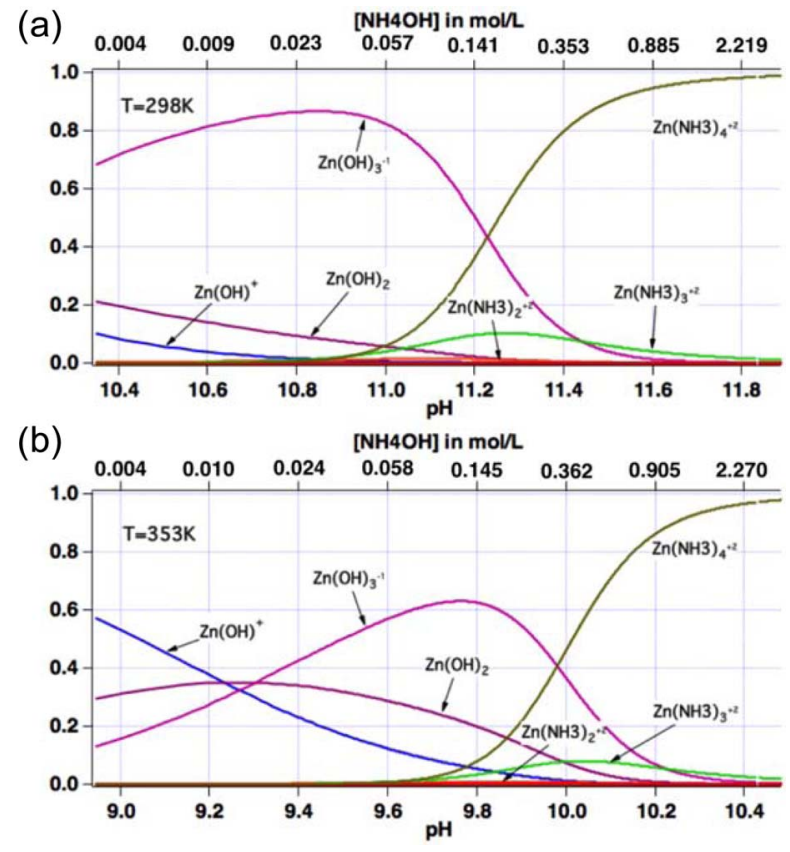

Figure 6. Species distribution diagrams of the system $\mathrm{Zn}-\mathrm{H}_{2} \mathrm{O}-\mathrm{NH}_{3}$ at (a) $298 \mathrm{~K}$ and (b) $353 \mathrm{~K}$ restricted to the $\mathrm{pH}$ range achieved with the addition of $\mathrm{NH}_{4} \mathrm{OH}$ from $0.003 \mathrm{M}$ to $3.34 \mathrm{M}$ and without additional $\mathrm{pH}$ modifiers. The top axes $\left[\mathrm{NH}_{4} \mathrm{OH}\right]$ values are stated for the corresponding $\mathrm{pH}$ values in the bottom axes. 


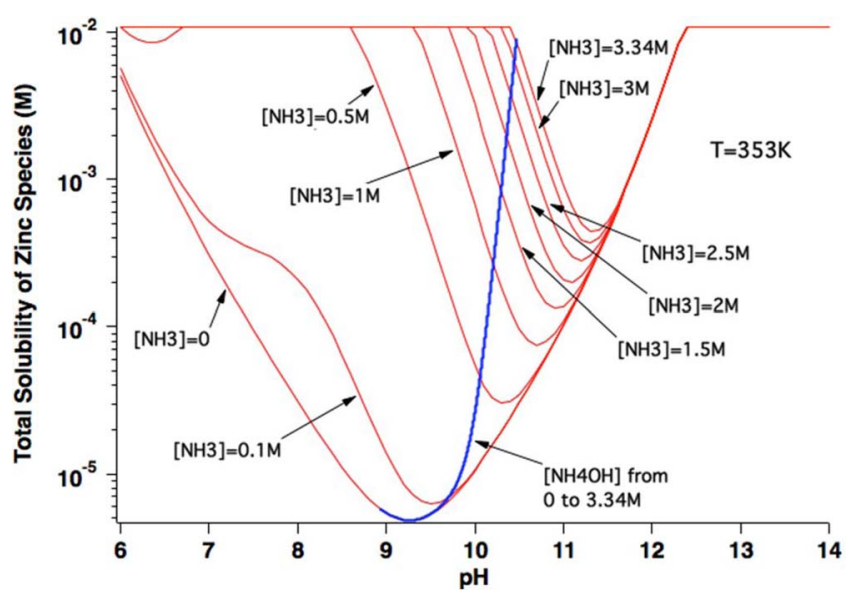

Figure 7. Total solubility diagram for the system $\mathrm{Zn}-\mathrm{SC}\left(\mathrm{NH}_{2}\right)_{2}-\mathrm{H}_{2} \mathrm{O}-\mathrm{NH}_{3}$ at $\mathrm{T}=353 \mathrm{~K}$ at different ammonium hydroxide concentrations. The blue line represents the total solubility of $\mathrm{Zn}$ species with only ammonium hydroxide.

$0.109 \mathrm{M}$ defined in the calculations. Concentrations can be identified at the intersections of the blue and red lines. When taken with Figures $5 \mathrm{~b}$ and $6 \mathrm{~b}$, the speciation underlying the total solubility curve derived purely from the addition of ammonium hydroxide shifts from $\mathrm{Zn}(\mathrm{OH})_{3}{ }^{-}$to $\mathrm{Zn}(\mathrm{NH} 3)_{4}{ }^{2+}$. For the purposes of $\mathrm{CBD}$, the calculated increased solubility for ammonia complexes favors the heterogeneous formation of $\mathrm{ZnOS}$ thin films and helps to mitigate problems associated with rapid homogeneous precipitation.

ZnOS film growth.- During a traditional chemical bath deposition, there exist three phases of a deposition sequence. The first of these is the induction phase where no observable growth takes place. During the second phase, the growth rate increases until a relatively linear growth is achieved. Finally, during the termination step, the reactants in the bath are depleted such that the growth rate decreases until no further growth is observed. ${ }^{16}$ Because this study employs a flow cell system to perform $\mathrm{ZnOS}$ depositions, the reaction mixture at the QCM surface has the same residence time throughout the entire deposition. Dynamic equilibrium is achieved similar to the second phase in a traditional CBD system.

Using the continuous flow method, the growth rate of the $\mathrm{ZnOS}$ thin film is stable, allowing the activation energy of film growth to be studied under constant experimental conditions. This method also allows for the growth of thick films, because no reactant depletion takes place that would terminate the reaction. Figure 8 shows linear growth curves for each experimental condition presented in this study. We report only on the linear growth regime as the nucleation periods can be somewhat variable.

A summary of the experimental results is provided in Table V, which lists the growth rates along with the activation energy results associated with each flow rate and stream composition. Activation energies were analyzed using the modified Arrhenius relation.

$$
\ln v=\ln A-\frac{E_{A}}{R T}
$$

where $v$ is the measured growth rate, $\mathrm{E}_{\mathrm{A}}$ is the activation energy, $\mathrm{R}$ is the ideal gas constant, $\mathrm{T}$ is temperature and $\mathrm{A}$ is a prefactor. Arrhenius plots are shown in Figure 9.

The activation energies in Table $\mathrm{V}$ are higher than those reported in the literature, ${ }^{5,16-18}$ which range between $7 \mathrm{~kJ} / \mathrm{mol}$ and $60 \mathrm{~kJ} / \mathrm{mol}$. Low activation energies result from the dominant growth mechanism that takes place during deposition and suggest that the film's growth rate is not limited by the chemical reaction rate. Recall that the two dominant growth mechanisms are the homogeneous and the heterogeneous mechanisms. The homogeneous mechanism involves the growth of $\mathrm{ZnOS}$ clusters that form when a free zinc ion reacts with a free anion in solution $\left(\mathrm{S}^{-2}\right.$ or $\left.\mathrm{OH}^{-}\right)$. The cluster grows by combining with other clusters or by acting as a nucleation site for further zinc ions and sulfur or oxygen containing anions. The homogeneous mechanism is characterized by a low activation energy, because the reaction is not sterically hindered by ligands in the zinc complex but rather by a physical process such as the adsorption or diffusion of $\mathrm{ZnOS}$ clusters onto the deposition surface. ${ }^{13}$ In contrast, the heterogeneous mechanism, or ion-by-ion mechanism, involves the adsorption of a zinc complex onto the deposition surface, followed by nucleophilic attack from a nearby anion. ${ }^{13}$ The activation energy for this process is
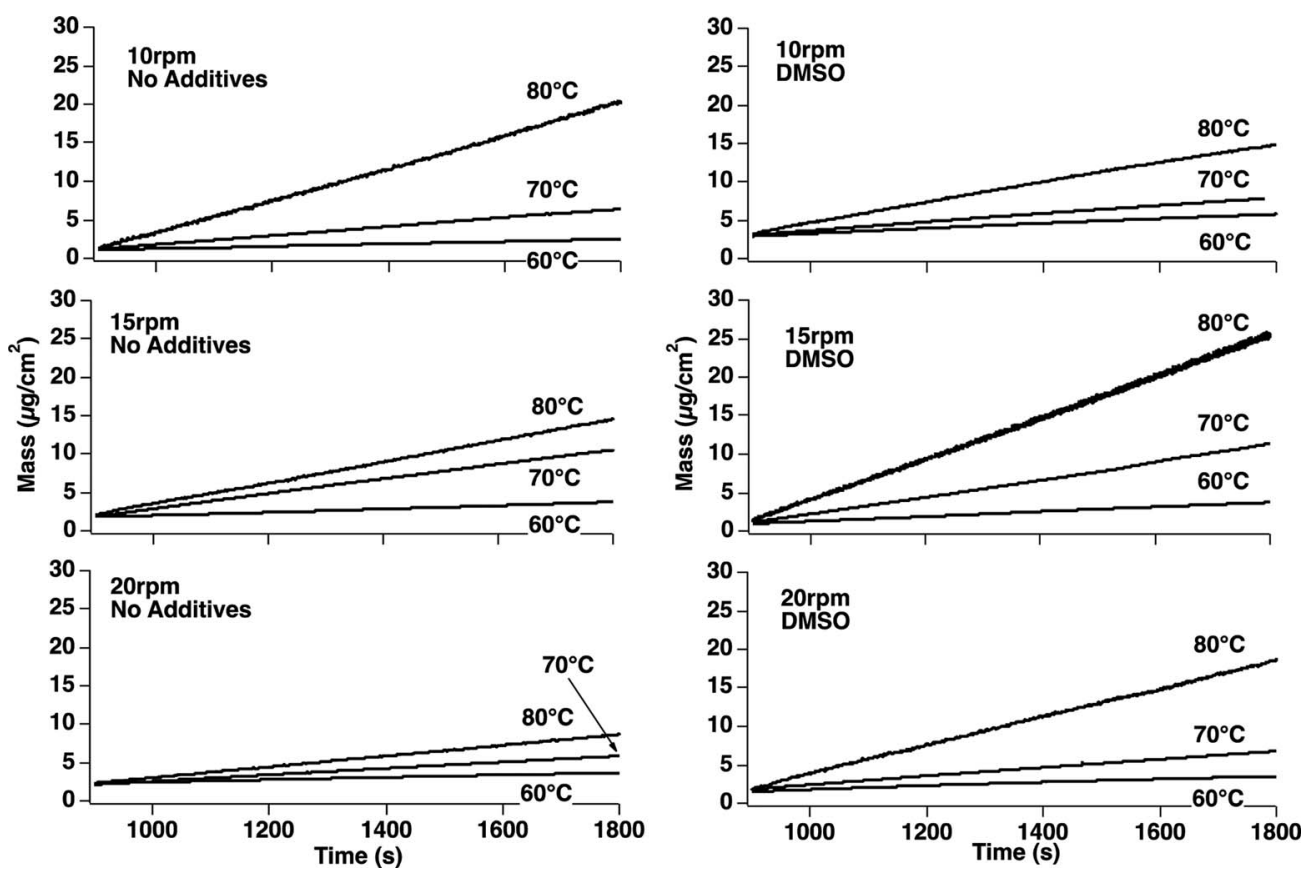

Figure 8. Plots for ZnOS mass deposited onto the QCM versus time. Different temperatures, solution compositions and pump speeds are indicated in each figure. Data are offset for clarity such that the first points in the plots overlap. Pump speeds of $10 \mathrm{rpm}, 15 \mathrm{rpm}$ and $20 \mathrm{rpm}$ correspond to $20 \mu \mathrm{L}, 30 \mu \mathrm{L}$ and $40 \mu \mathrm{L}$ total flow rates. 
Table V. Measured growth rates and activation energies of $\mathrm{ZnOS}$.

\begin{tabular}{ccccc} 
Type & $\begin{array}{c}\text { Flow Rate } \\
(\mu \mathrm{l} / \mathrm{s})\end{array}$ & $\mathrm{T}\left({ }^{\circ} \mathrm{C}\right)$ & $\boldsymbol{v}\left(\mu \mathrm{g} / \mathrm{cm}^{2} \mathrm{~s}\right)$ & $\mathrm{E}_{\mathrm{A}}(\mathrm{kJ} / \mathrm{mol})$ \\
\hline Plain & 20 & 59.9 & 0.0016 & $122 \pm 2$ \\
Plain & 20 & 70.1 & 0.0059 & \\
Plain & 20 & 80.9 & 0.0210 & \\
Plain & 30 & 60.3 & 0.0022 & $90 \pm 31$ \\
Plain & 30 & 70.2 & 0.0097 & \\
Plain & 30 & 80.4 & 0.0138 & $75 \pm 12$ \\
Plain & 40 & 60.6 & 0.0015 & \\
Plain & 40 & 70.5 & 0.0042 & \\
Plain & 40 & 80.6 & 0.0070 & \\
DMSO & 20 & 59.8 & 0.0032 & \\
DMSO & 20 & 70.2 & 0.0054 & \\
DMSO & 20 & 80.7 & 0.0130 & \\
DMSO & 30 & 60.8 & 0.0031 & $109 \pm 11$ \\
DMSO & 30 & 70.5 & 0.0113 & \\
DMSO & 30 & 80.2 & 0.0267 & \\
DMSO & 40 & 60.6 & 0.0022 & \\
DMSO & 40 & 70.5 & 0.0055 & \\
DMSO & 40 & 80.4 & 0.0184 &
\end{tabular}

high, because the zinc complexes adsorbing on the substrate surface are sterically hindered by their ammonia ligands, other complexes moving to the surface, and the substrate itself. The SDDs support this assertion by identifying the $\mathrm{Zn}\left(\mathrm{NH}_{3}\right)_{4}{ }^{2+}$ as the predominant source of cations under basic conditions with the higher $\mathrm{NH}_{4} \mathrm{OH}$ concentration.

The activation energies measured in this study are close to those found for $\mathrm{CdS}\left(\mathrm{E}_{\mathrm{A}}=85 \mathrm{~kJ} / \mathrm{mol}\right)$, which proceeds via the complex decomposition ion-by-ion mechanism. ${ }^{16,19}$ The large $\mathrm{E}_{\mathrm{A}}$ from the present case having short residence times suggests that $\mathrm{ZnOS}$ also proceeds via thiourea (likely complex) decomposition. Regarding the present study, at a flow rate of $40 \mu \mathrm{l} / \mathrm{s}$, the reactants have a residence time of one minute before arriving at the crystal surface, and two minutes at a flow rate of $20 \mu \mathrm{l} / \mathrm{s}$. With short residence times, there is lit-
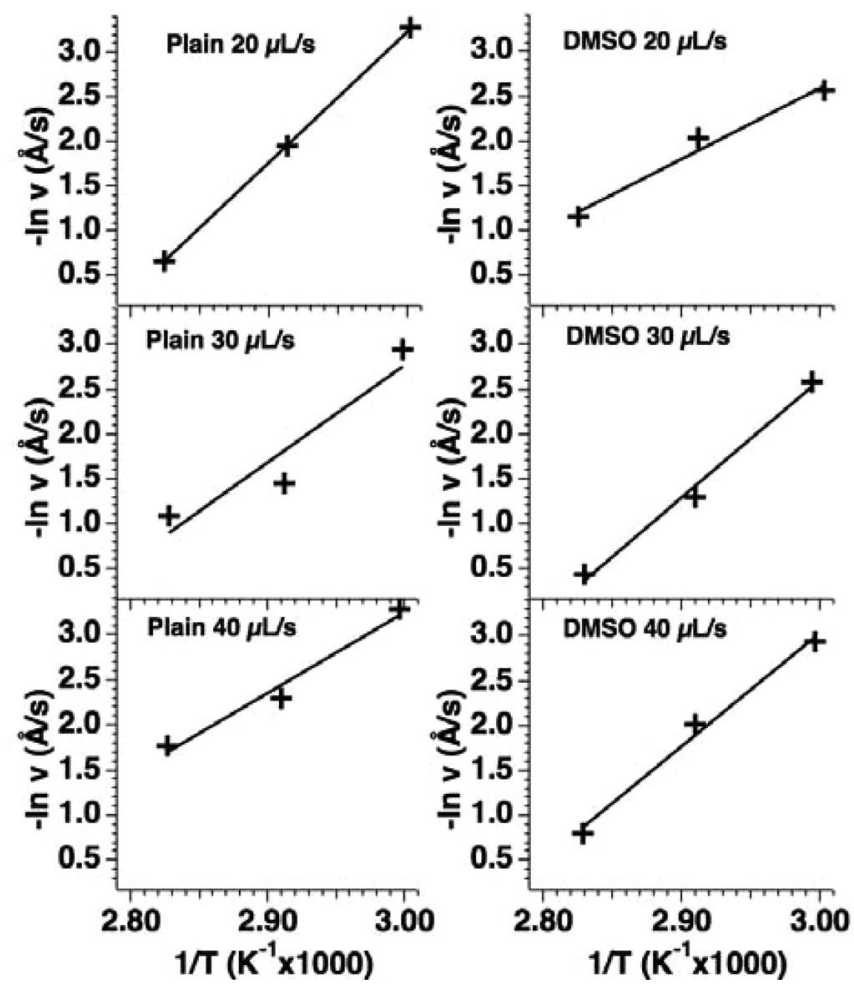

Figure 9. Arrhenius fits to growth rate data obtained for $\mathrm{ZnOS}$ on $\mathrm{SiO}_{2}$ coated QCM for different flow rates, without DMSO (left) and with DMSO (right). tle opportunity for the homogeneous mechanism to proceed. Hence, when considering the large activation energies in Table $\mathrm{V}$ and the deposition from continuously replenished reagents, it is reasonable to suggest that the growth of ZnOS films in this study is also limited by the decomposition of thiourea.

As the flow rate is increased, the activation energy increases for depositions involving DMSO, but decreases for the water only case. Based on the assumption that thiourea decomposition limits film growth, the increased $\mathrm{E}_{\mathrm{A}}$ can be explained by the decreased residence time of thiourea in the reactant stream, which would prevent the thiourea from decomposing into free sulfur anions. However, depositions that did not include DMSO as a co-solvent reveal a decreasing trend of the activation energy with increasing flow rate. Hence, the thiourea decomposition hypothesis is no longer valid. A decreasing trend of activation energy suggests that the growth mechanism is not chemical reaction limited but rather diffusion limited. Based on the opposite trends for $\mathrm{E}_{\mathrm{A}}$ versus flow rate in the DMSO and non-DMSO cases, we hypothesize that the inclusion of DMSO changes the growth mechanism of $\mathrm{ZnOS}$ from one that is limited by diffusion to one that is chemical reaction limited. This explains the trend of the activation energies without DMSO, since the increased flow rate increases the delivery of material at the substrate given that more solution is used for the deposition.

\section{Conclusions}

In this study, a complete model was presented that allowed a detailed analysis of speciation and total solubility when using ammonium hydroxide for zinc complexation without the addition of $\mathrm{pH}$ modifiers. We find that concentrations of ammonium hydroxide greater than $1 \mathrm{M}$ provide bath compositions with dominant $\mathrm{Zn}\left(\mathrm{NH}_{3}\right)_{4}{ }^{2+}$ speciation. Using this simple approach to control complex formation, ZnOS thin films were deposited on a QCM within a closed deposition system. The flow cell approach ensured that the reaction mixture arriving at the $\mathrm{SiO}_{2}$ surface maintained the same residence time such that the resulting growth rates were stable over long periods of time. Linear growth rates were used to generate Arrhenius plots from which activation energies were computed for each flow rate and composition. Conditions that included DMSO yielded activation energies that increased with higher flow rates, but those without DMSO exhibit the opposite behavior. Analysis suggests that inclusion of DMSO changes the growth mechanism from diffusion-limited to reaction-limited. The high activation energies found in this study are evidence that formation of $\mathrm{ZnOS}$ thin films in the flow cell proceeds via the heterogeneous mechanism rather than the homogeneous mechanism, which may be advantageous for adherent buffer layer films in thin film solar cells.

\section{Acknowledgments}

This work was supported in part by the U.S. Department of Energy, Office of Science, Office of Workforce Development for Teachers and Scientists (WDTS) under the Science Undergraduate Laboratory Internship (SULI) program. KXS and CLP were supported by the Laboratory Directed Research and Development (LDRD) Program at the National Renewable Energy Laboratory. NREL is a national laboratory of the U.S. Department of Energy Office of Energy Efficiency and Renewable Energy (Contract No. DE-AC36-08-GO28308) operated by the Alliance for Sustainable Energy, LLC. MR would also like to thank Rebekah Garris for outstanding support in this project.

\section{References}

1. I. Repins, M. A. Contreras, B. Egaas, C. DeHart, J. Scharf, C. L. Perkins, B. To, and R. Noufi, Prog. Photovolt: Res. Appl., 16, 235 (2008).

2. I. J. González-Panzo, P. E. Martín-Várguez, and A. I. Oliva, Journal of The Electrochemical Society, 161, D181 (2014).

3. C. Hubert, N. Naghavi, A. Etcheberry, O. Roussel, D. Hariskos, M. Powalla, O. Kerrec, and D. Lincot, Physica Status Solidi (a), 205, 2335 (2008).

4. C. Persson, C. Platzer-Björkman, J. Malmström, T. Törndahl, and M. Edoff, Phys. Rev. Lett., 97, 146403 (2006) 
5. I. J. González-Panzo, P. E. Martín-Várguez, and A. I. Oliva, Journal of The Electrochemical Society, 161, D761 (2014).

6. D. H. Shin, J. H. Kim, S. T. Kim, L. Larina, E. A. Al-Ammar, and B. T. Ahn, Solar Energy Materials and Solar Cells, 116, 76 (2013).

7. A. Wei, J. Liu, M. Zhuang, and Y. Zhao, Materials Science in Semiconductor Processing, 16, 1478 (2013).

8. K. Ramanathan, J. Mann, S. Glynn, S. Christensen, J. Pankow, J. Li, J. Scharf, L. Mansfield, M. Contreras, and R. Noufi, 38th IEEE PVSC Proceedings 001677, (2012)

9. K. X. Steirer, R. L. Garris, J. V. Li, M. J. Dzara, P. F. Ndione, K. Ramanathan, I. Repins, G. Teeter, and C. L. Perkins, Phys. Chem. Chem. Phys., 17, 15355 (2015)

10. C. Hubert, N. Naghavi, B. Canava, A. Etcheberry, and D. Lincot, Thin Solid Films, 515, 6032 (2007).

11. A. Goux, T. Pauporté, J. Chivot, and D. Lincot, Electrochimica Acta, 50, 2239 (2005).

12. C. Hubert, N. Naghavi, B. Canava, A. Etcheberry, and D. Lincot. in Photovoltaic Energy Conversion, Conference Record of the 2006 IEEE 4th World Conference. (2006).
13. J. M. Doña and J. Herrero, Journal of The Electrochemical Society, 141, 205 (1994).

14. R. S. Araoz, PhD Dissertation, University of Berlin: Berlin, Germany (2009),

15. S. Tec-Yam, J. Rojas, V. Rejón, and A. I. Oliva, Materials Chemistry and Physics, 136, 386 (2012).

16. G. Hodes, Chemical Solution Deposition of Semiconductor Films, Marcel Dekker, Inc. (2002).

17. H. Ke, S. Duo, T. Liu, Q. Sun, C. Ruan, X. Fei, J. Tan, and S. Zhan, Materials Science in Semiconductor Processing, 18, 28 (2014).

18. L. Qi, G. Mao, and J. Ao, Applied Surface Science, 254, 5711 (2008).

19. C. Voss, Y. J. Chang, S. Subramanian, S. O. Ryu, T. J. Lee, and C. H. Chang, Journal of the Electrochemical Society, 151, C655 (2004).

20. C. L. Perkins, J. Phys. Chem. C. 113, 18276 (2009).

21. C. S. Lu and O. Lewis, J. Appl. Phys. 43, 4385 (1972).

22. A. Bayer, D. S. Boyle, and P. O'Brien, J. Mater. Chem., 12, 2940 (2002).

23. F. Gaizer and H. B. Silber, Journal of Inorganic and Nuclearchemistry, 42, 1317 (1980). 